\title{
Library and Information Science Research Winter 2007 and Spring 2008: A Bibliography of Master's Papers from the University of North Carolina School of Information and Library Science
}

The following Master's papers were submitted in partial fulfillment of the requirements for the Master of Science in Library Science degree or the Master of Science in Information Science degree at the School of Information and Library Science at the University of North Carolina at Chapel Hill. The Master's papers are available online at: http://sils.unc.edu/itrc/mpi/.

\section{Winter 2007}

Allen, Elizabeth R. "The Impact of School Libraries on Student Achievement in North Carolina Charter Schools." December, 2007. 25 pages.

Belvin, Dena L. "Facilitating Retrieval of Sound Recordings for Use by Professionals Treating Children with Asperger's Syndrome.” July, 2007. 41 pages.

Beres, Tibor. "DAIRSACC - Do Acronyms Influence Reading Speed and Content Comprehension?" December, 2007. 105 pages.

Brodsky, Marc D. "Special Collections-Challenges and Contexts: A Case Study.” November, 2007. 90 pages.

Crow, Amy. "Planning for Retrospective Conversion of Legacy Finding Aids in the Southern Historical Collection at the University of North Carolina at Chapel Hill: A Case Study." November, 2007. 41 pages.

Daly, Emily K. “Librarians’ Use of Instructional Techniques: Effective in Enhancing Chat Reference Services from the Patrons' Perspective?" November, 2007. 83 pages.

Edmunds, Douglas B. "The Impact of A Cognitive Flexibility Hypermedia System on Preservice Teachers' Sense of SelfEfficacy." November, 2007. 30 pages.

Fain, Mary Katherine. "Bookmobile Staff Perceptions on Bookmobile Service.” November, 2007. 103 pages.

Floyd, Vanessa C. "United States Government Discourse and Diplomacy in the Era of African Independence Movements: A Selected Annotated Bibliography of Federal Government Information." November, 2007. 48 pages.

Fox, Alexandra E. "Battle of the Music Recommender Systems: User-Centered Evaluation of Collaborative Filtering, Content-Based Analysis and Hybrid Systems." November, 2007. 104 pages.
Gill, Jessica H. "Establishing an elementary graphic novel collection: An analysis of the most frequently utilized collection development resources." December, 2007. 41 pages.

Horowitz, Stephanie A. "Faculty Status and the Publication Impact of ARL Librarians.” November, 2007. 29 pages.

Howard, Bryan E. "Evaluation of Text Classification Accuracy." November, 2007. 50 pages.

Howson, Elizabeth Walker. "A Content Analysis on the Meaning of Disenchantment in Fairy Tales." November, 2007. 32 pages.

Hubbard, Melissa A. "An Analysis of the Holdings of Certain Lady Gregory Monographs at the University of North Carolina at Chapel Hill's Rare Book Collection.” December, 2007. 47 pages.

Kumar, Amit. "Digital Library of Dental Radiographs." November, 2007. 60 pages.

Laster, Sharalyn J. "Works Created Under Federal Contracts: Copyright and Digital Preservation." November, 2007. 45 pages.

Lukach, Katherine M. "Transformative Encounters in the Works of Neil Gaiman.” December, 2007. 52 pages.

Martin, Scott T. "The Federal Goal of Making All Healthcare Records Electronic by 2014: Differing Viewpoints." August, 2007. 30 pages.

Miller, Rebecca K. "The Value of Values-Based Literature: An Exploration of Librarianship's Professional Discussion of Core Values." December, 2007. 64 pages.

Murphy, Kate E. "Unique Library Partnerships: A Comparative Case Study." November, 2007. 52 pages. 
Pope, Mark W. "Automatic Classification of Online News Headlines.” November, 2007. 66 pages.

Robinson, Jillian E. "A Study of Social Media Marketing in North Carolina Special Libraries." November, 2007. 56 pages.

Sheode, Janhavi. "A usability study of Chapel Hill Transit and Triangle Transit Authority Web sites." November, 2007. 54 pages.

Shields, Alison M. "Current Priorities and Future Directions: A Content Analysis of Active Strategic Planning Goals of Public Libraries in the United States." November, 2007. 71 pages.

Sobel, Karen D. "Promotion of Library Reference Services to First-Year Undergraduate Students.” November, 2007. 53 pages.

Sullivan, Tessa. "Current Metadata Process Practices." August, 2007. 47 pages.

\section{Spring 2008}

Adamson, Stephanie C. "Soliciting User Contribution in the Modern Digital Library: A Critique Framework for Evaluating Methods and A Case Study Recommendation for A Digital Library of Historical Materials.” April, 2008. 36 pages.

Arnaudin, Edwin B. "Mormon Vampires: The Twilight Saga and Religious Literacy." April, 2008. 102 pages.

Bailey, Earl W., Jr. "A Comparison of Retrieval Strategies Between High Performers and Low Performers of an Experimental IR System.” April, 2008. 32 pages.

Baldwin, Timothy D. "Communicating with University Students in an Emergency: A Survey of What They Know and How to Reach Them." April, 2008. 67 pages.

Bates, Jennifer E. "Finding Quality Reviews for Young Adult Books." February, 2008. 35 pages.

Berberian, Laura J. "Official United States Documents on the Armenian Genocide: An Annotated Bibliography." April, 2008. 44 pages.

Bertling, Carrie M. "Exhibitionism: Improving Access to Oral Histories through Online Exhibits." April, 2008. 62 pages.

Boxill, Lisa M. "Licenses and Electronic Resource Management Systems: An Evaluation of Current Issues and Practices.” April, 2008. 30 pages.
Carrier, Sarah W. "The Dryad Repository Application Profile: Process, Development, and Refinement." April, 2008. 69 pages.

Castaldo, Jennifer C. "Marketing Electronic Resources from the Academic Library Homepage.” April, 2008. 53 pages.

Craft, Anna R. "Putting Web Server Log Files to Work in Special Collections.” April, 2008. 64 pages.

Crutchfield, Trisha M. "Where are the Patients? - Missed Medical Appointments and Preferred Reminders among College Students.” March, 2008. 62 pages.

Dickie, Grant. "Perspectives on Text Encoding Initiative Projects from Current Digital Library Managers." April, 2008. 36 pages.

Dimac, Lynn D. "The Depiction of Information Technology in Children's Picture Books.” April, 2008. 52 pages.

Donaldson, Devan R. "The Perfect Match: The Relationship between User Vocabulary and Metadata Vocabulary and Enterprise Web Information Retrieval.” April, 2008. 56 pages.

Donnelly, Caitlin R. “"That's Just Like a Boy”: A Content Analysis of Masculinities in Hardy Boys Mystery Stories, 1927-1932." April, 2008. 77 pages.

Etchison, Whitney D. “A Descriptive Study of Resources for Hispanic Students in North Carolina Public K-8 School Library Collections.” April, 2008. 42 pages.

Fitzgerald, Meghan A. "Young Adult Fantasy Fiction in Recent Years: A Selective Annotated Bibliography." April, 2008. 68 pages.

Fragola, Marian G. "Intergroup Dynamics: Librarians and Paraprofessionals in the Workplace.” April, 2008. 36 pages.

Gorman, Elizabeth D. "Purposes Behind Summer Reading Assignments.” March, 2008. 57 pages.

Gransee, Sarah M. "Mother-Daughter Relationships in Young Adult Literature: A Content Analysis of Adolescent Individuation.” April, 2008. 43 pages.

Gregg, Elizabeth J. "Public Library Programming for Youth: Creative Writing as a Tool for Literacy and Adolescent Development." April, 2008. 38 pages.

Greitzer, PaulD. "Educating Tomorrow's OrchestraLibrarian: An Evaluation of LS Curricula for Special Libraries." May, 2008. 40 pages.

Hailey, Tom. "The Wilson Hall Exhibit: The Making of an Education Exhibit.” April, 2008. 61 pages. 
Halsband, Megan C. "Stereographs as Scholarly Resources in Academic Libraries and Special Collections." April, 2008. 51 pages.

He, Li. "Comparison of Alternative Methods of Tag Presentation on Chinese Websites.” April, 2008. 34 pages.

Herzong, Elizabeth Ronan. "Marketing the Digital Divide: Case Studies of Two Telecenters in Thailand.” April, 2008. 76 pages.

Hollingsworth, Douglas C. "Member Perceptions of the HBCU Library Alliance: A Case Study of Inter-Institutional Collaboration Models.” May, 2008. 50 pages.

Huffman, Noah G. "Search Features and Other Characteristics of SML Retrieval Systems for EAD Finding Aids: A Content Analysis.” April, 2008. 56 pages.

Hughes, Annie M. "Publication Behaviors of the Signers of the Public Library of Science (PLoS) 'Open Letter to Scientific Publishers.” April, 2008. 51 pages.

Hurst, Emily J. "An Assessment of the Readability of Recommended Popular Consumer Health Titles: Implications for Collection Development.” April, 2008. 28 pages.

Irvine, Ann K. "Natural Language Processing and Temporal Information Extraction in Emergency Department Triage Notes.” April, 2008. 56 pages.

Jin, Jie. "NC Health Info and Go Local: An Analysis of Web Change Impacts on Metadata Quality and A Proposed Framework for Semi-Automatic Metadata Maintenance." April, 2008. 35 pages.

Johnson, Nicholas A. "An Investigation of the Aesthetic Fidelity of Live Websites." April, 2008. 42 pages.

Jorgensen, Rachel O. "The Women Librarians of the LandGrant Colleges in the West and Midwest, 1862 - 1920: A Preliminary Study.” April, 2008. 99 pages.

Kahn, Sarah N. “Storytime: A Storyteller's Database, Project Report.” April, 2008. 37 pages.

King, Emily M. "E-learning, One Course at a Time: A Usability Study of the UNC Library Course Pages." April, 2008. 39 pages.

King, Jared P. "Web Usability on an International Scale: A Content Analysis." April, 2008. 34 pages.

Lawson, David R. "An Evaluation of Arabic Transliteration Methods.” April, 2008. 55 pages.
Less, Anne M. "Community Informatics: A Bibliometric Study of Scholarly Influence.” April, 2008. 55 pages.

Lown, Cory. "A Transaction Log Analysis of NCSU's Faceted Navigation OPAC.” April, 2008. 66 pages.

Lucas, Daniel V. “A Product Review of Zotero.” April, 2008. 46 pages.

Luden, Stacey M. "Creation of 'Storytime: A Database for Storytellers' Website.” April, 2008. 13 pages.

Lynch, Grant C. "Using Tag Clouds to Analyze Content in Public Library Mission Statements.” April, 2008. 63 pages.

MacPherson, Meredith A. "Alternative Careers for Graduates of Library Science Programs: Are Library Schools Doing Enough?” April, 2008. 60 pages.

Mall, Nicholas A. "Spanish-Language Electronic Access in the Public Library." April, 2008. 51 pages.

Marsh, Megan S. "Serving the Patron: Tradition, Ideology and Change in Public Libraries." May, 2008. 35 pages.

Matson, Elizabeth Anna. "The Birth of Children's Book Reviews, 1918-1929.” April, 2008. 88 pages.

McCrea, Briynne N. R. "Curriculum Support in Public Libraries: A Descriptive Analysis of Collections in North Carolina's Triangle Region.” April, 2008. 61 pages.

McGlothlin, James. "Gimme That Old Time Religion: Practicing the Library Faith in the New Millennium." April, 2008. 123 pages.

Merriman, Jennifer. "Using Digitized Primary Sources in the North Carolina K-12 Classroom.” April, 2008. 55 pages.

Morgan, Amy E. “An Analysis of Holdings of Selected Works of Seamus Heaney from 1965 to 1995 in the University of North Carolina at Chapel Hill's Rare Book Collection." April, 2008. 67 pages.

Neuerburg, Laurie J. "The Professional Discussions of Catalogers: A Content Analysis of AUTOCAT.” April, 2008. 37 pages.

Noll, Hannah M. "Where Google Stands on Art: An Evaluation of Content Coverage in Online Databases." April, 2008. 43 pages.

Nowicki de Guerra, Regina. "Defining the Role of the Public Library: A Qualitative Analysis of Mission Statements." April, 2008. 100 pages.

O'Gara, Genya M. "Front and Center: The Role of Libraries and Copyright in the Digital Age." April, 2008. 72 pages. 
Orphanides, Andreas K. "Extraction of Natural-Language Dates and Comparison of Dates in Hypothesis and Text to Identify Negative Textual Entailment." April, 2008. 66 pages.

Peper, Michael T. "The Effect of Remote Storage on the Use of Books." April, 2008. 41 pages.

Peterson, Jessica A. "Checking Our or Checking Into Reading? The Borrowing Habits of Elementary School Children In Relation to Gender, Age, and Reading Ability." April, 2008. 50 pages.

Peterson, Sarah K. "My Kingdom for a (Digital) Horse: Perceptions of Virtual Property Rights in Second Life." April, 2008. 48 pages.

Rainey, Allison S. "An Examination of the Impact of Organizational Diversity." April, 2008. 70 pages.

Reed, Kenneth. "The Digital Monograph: Preservation and Repurposing of the Academic Monograph at University Presses.” April, 2008. 46 pages.

Reynolds, Lisa. "An art provenance research guide for the researcher and librarian: A list of resources." April, 2008. 45 pages.

Ritter, Lindsey. "Patient Education and Consumer Health Information: A Study of the Patient and Family Resource Center at the UNC-CH Cancer Center." April, 2008. 36 pages.

Roberson, Casey A. "Dimensions of Quality and Diversity in Graphic Novel Collections." April, 2008. 49 pages.

Rodriguez, Marcos A. "Knowledge Discovery in a Review of Monograph Acquisitions at an Academic Health Science Library." March, 2008. 45 pages.

Rudolph, Megan A. "Librarians in Film: A Changing Stereotype.” April, 2008. 40 pages.

Russ, Johanna M. "Comparing Evaluation Methodologies for a Digital Exhibition: The End of Tobacco Road: Scenes from Liggett \& Myers Tobacco Company's Final Days in Durham, North Carolina, 1999." April, 2008. 46 pages.

Ryan, Melinda J. T. "Perceptions of Library Gamers at the Public Library of Charlotte and Mecklenburg County's Teen Loft.” April, 2008. 36 pages.

Samouelian, Mary E. "Embracing Web 2.0: Archives and the Newest Generation of Web Applications." April, 2008. 66 pages.
Sherman, Stephen C. "A User-centered Evaluation of the North Carolina State University Libraries Learning Commons." April, 2008. 74 pages.

Sipes, Jacqueline R. "Humanities Graduate Students' Use of Library Instructional Resources.” April, 2008. 66 pages.

Solomon, Jennifer H. "University Writing Center and Library Collaborations: An Analysis of Writing Center and Library Websites at ARL Affiliated Institutions." April, 2008. 33 pages.

Speace, Gillian M. "The Mabinogi as Children's Literature." April, 2008. 86 pages.

$\mathrm{Su}$, Wei-Hsin. "A Visual Enhancement for Metadata Generation Tools: A Semi-Automatic Approach via KWIC and Highlighting." April, 2008. 48 pages.

Thompson, Abbey E. "Playing Tag: An Analysis of Vocabulary Patterns and Relationships Within a Popular Music Folksonomy.” April, 2008. 33 pages.

Tomlin, Patrick L. "The Archival Unconscious: Thomas Owen and the Founding of the Alabama Department of Archives and History." April, 2008. 68 pages.

Venie, Todd M. "Essential Research Skills for New Attorneys: A Survey of Academic and Practitioner Law Librarians." April, 2008. 48 pages.

Vernon, Katrina C. "Street Literature in Five North Carolina Public Library Systems.” April, 2008. 37 pages.

Wallace, William S. "The Perimeter of Security: Policy as the Bridge between Library Security Philosophy and Library Security Practice.” April, 2008. 44 pages.

Watson, Elizabeth A. "Going Fishing: Serendipity in Library and Information Science.” April, 2008. 76 pages.

Watts, Lashonda D. "No Prescriptions Needed: Use of Trustgarnering Features by Illegal Online Pharmacies." April, 2008. 26 pages.

Zhu, Peiwen. "Web Annotation Systems: A Literature Review and Case Study." April, 2008. 36 pages. 